\title{
The Impact of Terrorism Activities As Threat To Unstable Economy on Foreign Direct Investments FDI: A Panel Study of 33 Sub-Saharan African Countries
}

\author{
Yao HongXing, Winfred Okoe Addy, Samuel Kofi Otchere, Robert Yao Aaronson, \\ and Jean-Jacques Dominique Beraud
}

\begin{abstract}
The study aims to assess the impact of terrorism activities on foreign direct investment in a panel study of 33 Sub-Saharan African countries. In order to achieve the objective of the study, it employed panel data methodologies such as GLS random-effect, ML randomeffect, fixed effect regression, generalized linear model and multivariate regression methods to enable it make statistically and robust inference or conclusion. However, the study found that there is an inverse linear relationship or impact on foreign direct investment in Sub-Saharan Africa. Also, the study found out that economic growth and foreign direct investment are inversely related and corruption control has positive and direct linear relationship with foreign direct investment. As the study focused on the linear relationship of terrorism activities and foreign direct investments, it recommends further studies into the subject-matter by employing the non-linear approaches to ascertain the non-linear relationship between the two.
\end{abstract}

Index Terms - Foreign Direct Investment; Terrorism activities; Political instability; Sub-Saharan Africa.

\section{INTRODUCTION}

Foreign direct investment and global trade are the common measure of globalization since 1985 other than the world gross domestic product (GDP). The rapid growth of foreign direct investment from that time is as a result of loosening of foreign direct investment regulations and state enterprises privatization. Many have argued that foreign direct investment potentially has significant impact oon developing economies than international trade due to its prospects of import of new advance technologies, management and product expertise but not just the capital inflows only [20]. Most importantly, foreign direct investment enables foreign businesses to grow beyond their

Published on August 5, 2020.

Yao Hong Xing, Jiangsu University, School of Finance and Economics, China. Winfred Okoe Addy, Jiangsu University, School of Finance and Economics,

China.

(corresponding e-mail: addywinfred@gmail.com)

Samuel Kofi Otchere, Jiangsu University, School of Finance and Economics, China. domestic markets to international markets to benefit from larger economies of scale to produce cheaper products to serve larger market to gain greater market share.

In developing economies, foreign direct investments have good prospects and fortunes for their economic development but one of the impediments that could hinder foreign direct investments is the activities and destructions of terrorism which mostly causes chaotic and unstable economies. In the last 30 years, terrorism and act of violence have become global concern; taking into account previous terrorist attacks in New York (September 11, 2001), London, Madrid, Kenya (El shabab), Nigeria (Bokoharam) etc. threatened the world's peace and development. However, there is an increasing threats from terrorists groups in the world which usually create economic misfortunes, fear and panic. Eventhough, advancement of technologies have positive impact on socio-economic development, they have also given way for terrorism activities because most of the acts are done with sophisticated arsenals; these acts have an inverse impact on foreign direct investment prospects. Moreover, no foreign investor will risk to invest in war-prone or highly terrorists dominated economies due to fear of loss of investment. Foreign direct investment could have more positive economic impact than negative impact.

Act of violence, crime and terrorism as possible hinderances were not considered in previous studies but rather focused on the economic risk that can affect foreign direct investments such as governments' effectiveness, act of corruption, inflation and per capita income factors. In recent times, some studies considered research into the nexus of terrorism and foreign direct investment. [9] studied the possible effect of terrorism through ethnic pressures, social instability, armed war and assassination on foreign direct investment inflows. They incorporated an index which comprised of street violence, language, religious and ethnic embodiment; in their conclusion, they inferred that terrorism acts and foreign direct investments are inversely related. To buttress their view, [20] investigated the relationship between acts of terrorism (conflicts and

Robert Yao Aaronson, Jiangsu University, School of Finance and Economics, China.

Jean-Jacques Dominique Beraud, Jiangsu University, School of Finance and Economics, China. 
violence) and foreign direct investment inflow in developed countries with focus on the economic sector impact, he concluded that there is an existence of inverse relationship or correlation between terrorism and FDI inflows into developed countries. However, he argued that among the categories of industries that he sampled thus 12 , foreign direct investment inflows to construction, manufacturing and trade sectors have an inverse and statistically significant relationship with terrorism activities. [3] also share the same opinion as he concluded from his studies that there is a significant negative relationship between terrorism and foreign direct investment inflows. These findings are supported by studies from [1], [2], [4], [6]-[11], [13], [19].

Nonetheless, few studies share divergent views and they posit that there are mixed results with regards to the relationship between terrorism and foreign direct investments thus neither positive or negative[21]. The study's motivation stems from these arguments which have diverse conclusions and also there are few literature on the nexus of terrorism and foreign direct investment in the Sub-Saharan Africa. The objective of the study is to assess the long run impact of terrorism through political instability, violence and crime as threat to unstable economy on the inflows of foreign direct investment in the SubSaharan African region. The study contributes to the argument pertaining to terrorism activities and their economic impact for policy influence and academic perusal.

The organization of the study encompasses part one which is the introduction of the study and literature review, part two which consists of the study's data and methodology, part three which presents the empirical findings and discussions and the last part (5) concludes the study.

\section{Data And Methodology}

\section{A. Data}

The study utilized secondary data for its empirical study from World Development Indicators and Worldwide Governance Indicators for the period of 2000 to 2014. The study adopted five variables to assess the impact of terrorism activities as threat to unstable economy of foreign direct investment in SubSaharan Africa. However, the study used a panel study approach which it used 33 countries for cross sectional study to unravel the relationship that exist between terrorism (political instability) and foreign direct investments. The details of the variables can be found in Table 1 .

\section{B. Methodology}

This is a panel study of 33 Sub-Saharan African countries hence the use of panel data methodologies. The methodologies that the study employed are; unit root test, correlation matrix, Pedroni and Johansen Fisher combined cointegration tests, GLS random-effect, ML random-effect, Fixed effect regression, Generalized linear model and Multivariate regression.
TABLE 1: Variable Description And Source

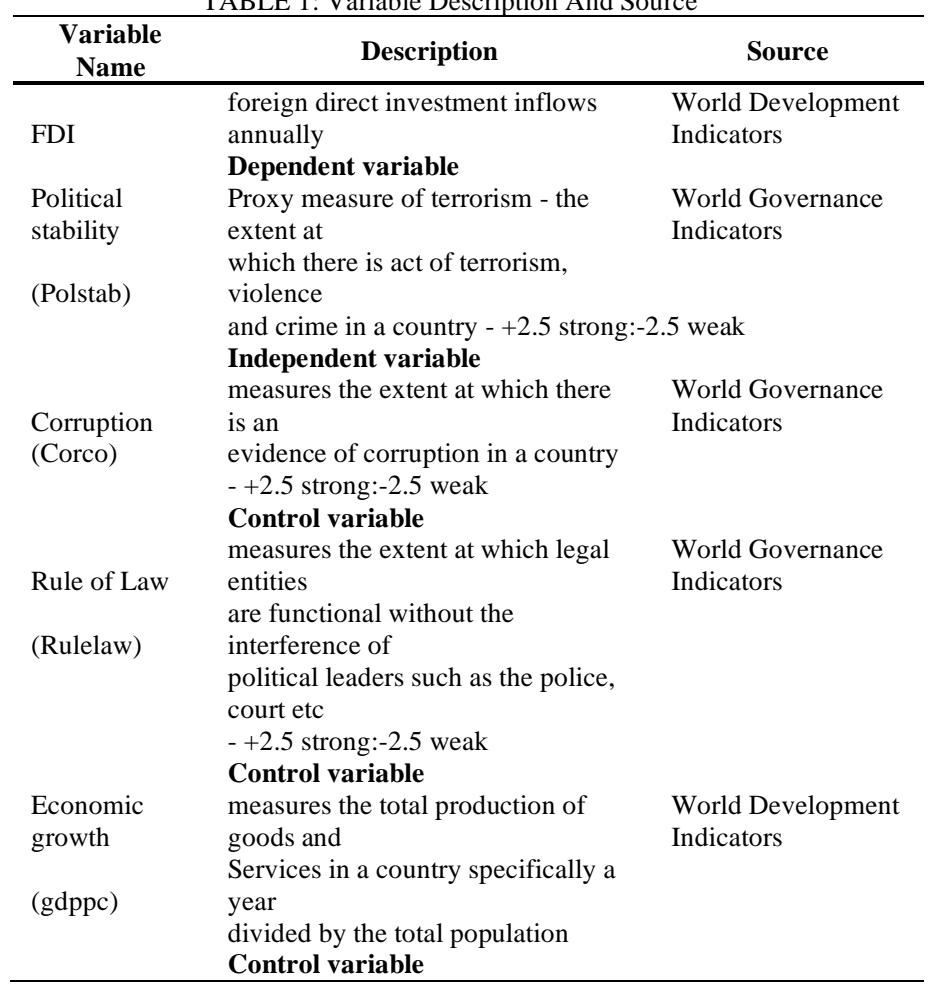

To be able to achieve the study's objective of assessing the impact of terrorism activities as threat to unstable economy on foreign direct investments in Sub-Saharan African countries; the study follows an empirical and scientific approach to analysis the data to make statistical conclusion. Therefore, the first approach that the study embarks on is the unit root tests after running the summary statistics to identify the mean, median, minimum and maximum values of the variables. The unit root tests use four (4) approaches thus [14], [12], ADFFisher and PP-Fisher tests[15] to prove evidence of stationarity in the variables. The objective of the unit root test is to find out whether there is unit root in the variables in order to accept the null hypothesis which states that there is an evidence of unit root in the variable but if the test result proves otherwise then the study can reject the null hypothesis to carry on with its data analysis. It is imperative to test for multicollinearity to avoid the proble of collinearity hence the study performs correlation matrix to check for multicollinearity and the correlation between the dependent and independent variables after the unit root tests. The rule of thumb of the correlation matrix analysis posits that no two independent variables should be highly correlated with the dependent variable at coefficient of $-/+0.70$ or above. After it has been evidenced that there is no problem of multicollinearity then the next step of the study is to find out whether there is a long run relationship between the dependent and independent variables. Therefore, the study will use $[17,18]$ and Johansen Fisher combined cointegration to ascertain the long run relationship in order to confirm that the coefficient of the study's regression methods have long run relationship. 
The subsequent test of the study is to perform the data analysis to assess the impact of terrorism as threat to unstable economy of foreign direct investments hence the use of GLS random effects, ML random effects and fixed effects to find out the linear relationship between the dependent and independent variable. Moreover, in order to confidently infer on the results produced by three methods, the study also uses Generalized linear model and Multiviarate regression as robust check methods to statistical inference.

The study uses econometric model and the model can specified as:

FDI $=f$ (Terrorism, corruption, rule of law, Economic growth) (1)

$\operatorname{lnfdiit}=\beta_{0}+\beta_{1}(\text { Polstab })_{i t}+\beta_{2}(\text { Corco })_{i t}+\beta_{3}(\text { rulelaw })_{\mathrm{it}}+\beta_{4}(\text { lngdppc })_{\mathrm{it}}+$ $\varepsilon_{\text {it }}$

In equation (2), $\beta_{0}$ stands for the coefficient of intercept or slope, polstab stands political stability and it is the measure of terrorism, corco stands for corruption control, rulelaw stands for rule of law, lngdppc stands for gross domestic product per capita and measures economic growth, lnfdi stands for foreign direct investments, $\varepsilon$ stands for the stochastic error term, i stands for the cross section of 33 Sub-Saharan African countries and $\mathrm{t}$ stands for the time period from 2000 to 2014. Foreign direct investment and gross domestic product per capita (Economic growth) are in their natural logarithm hence lnfdi and lngdppc.

\section{EMPIRICAL FINDINGS AND DisCUSSION}

\section{A. Summary statistics}

Table 2 below describes and summarizes the statistics of the variables used for the study. From the table, it can be reported that foreign direct investment in the Sub-Saharan Africa grew at an average of $1.892 \%$ annually and the maximum growth as well as the minimum growth rate were $21.134 \%$ and $-3.823 \%$ respectively. To account for the economic growth the region, it grew at an average of $7.134 \%$ annually with maximum and minimum growth rate of $9.920 \%$ and $5.267 \%$ respectively. In terms of terrorism activities thus violence, crime and political instability acts, Sub-Saharan Africa region score -0.438 on the average annually with a maximum and minimum score of 1.118 and -2.477 respectively. It clearly confirms that the fight against terrorism activities have not promising which needs more room for improvement. Corruption control has also not received the needed fight hence scored an average of -0.555 annually. Also, the practice of rule of law is not strengthened enough as the average score per year in the sample period was -0.534 . In the table 2, the results of the Kurtosis test posits that the distribution of the variables are positive and leptokurtic. The Skewness test also confirms that the distribution are positively skewed hence majority of the data are on the positive side showing that the mean of the variables are larger than the median. Furthermore, the Jarque-Bera test confirms that the distribution are not normally distributed except rule of law.

\begin{tabular}{llllll}
\multicolumn{7}{c}{ TABLE 2: Summary Statistics } \\
\hline Mean & Infdi & Ingdppc & polstab & rulelaw & corco \\
Median & 1.892 & 7.134 & -0.438 & -0.534 & -0.555 \\
Maximum & 2.489 & 6.896 & -0.250 & -0.517 & -0.600 \\
Minimum & -3.823 & 5.267 & -2.477 & -2.009 & -1.773 \\
Std. Dev. & 1.624 & 1.143 & 0.808 & 0.592 & 0.552 \\
Skewness & 2.800 & 0.607 & -0.434 & 0.098 & 0.527 \\
Kurtosis & 41.712 & 2.257 & 2.501 & 3.126 & 3.328 \\
Jarque-Bera & 31556.660 & 41.840 & 20.696 & 1.125 & 25.123 \\
Probability & 0.000 & 0.000 & 0.000 & 0.570 & 0.000 \\
Observations & 495 & 495 & 495 & 495 & 495 \\
\hline
\end{tabular}

Foreign direct investment and economic growth are in their natural logarithm hence lnfdi and lngdppc.

\section{B. Panel unit root tests}

To ascertain whether there is no evidence of unit root in the variables, the study employed the tests of Levin, Lin \& Chu [14], Im-Pesaran \& Shim [12] and, ADF-Fisher and PP-Fisher [15]. The evidence of the tests can be found in table 3 . The result confirms that at level form only lngdppc showed evidence of unit root in two tests thus Im-Pesaran and Shim, and ADFFisher tests) but was stationary in the Levin, Lin \& Chu and the PP-Fisher tests. However, at first difference all the variables showed stationarity; therefore, the study can confidently conclude that at first difference all the variables are stationary. Therefore, the study rejects the null hypothesis that there is presence of unit root in the variables.

\section{Correlation Matrix}

Correlation matrix is computed to find the correlation linkage between the dependent and independent variables. Most importantly, it is also computed to find out whether there is problem of multicollinearity in the variables. Perhaps, the rule of thumb of collinearity states that no two independent variables should be highly correlated with the dependent variable at coefficient $-1+0.70$ or more. From table 4 , it is established that economic growth has negative and significant correlation with foreign direct investment. Terrorism (Political instability) has negative and statistically significant correlation with foreign direct investment. Corruption showed a positive and insignificant correlation with foreign direct investment as well as rule of law which also showed insignificant correlation with foreign direct investment. 
TABLE 3: Unit Root Tests

\begin{tabular}{|c|c|c|c|c|c|}
\hline & Ingdppc & polstab & Infdi & rulelaw & corco \\
\hline \multicolumn{6}{|l|}{ Level form } \\
\hline Levin, Lin \& Chu t* & $-4.119 * * *$ & $-8.096 * * *$ & $-3.665 * * *$ & $-14.967 * * *$ & $-32.022 * * *$ \\
\hline Im, Pesaran and Shin & 2.359 & $-6.480 * * *$ & $-2.363 * *$ & $-11.328 * * *$ & $-13.966 * * *$ \\
\hline ADF - Fisher & 64.878 & $173.463 * * *$ & $99.985 * *$ & $221.689 * * *$ & $224.600 * * *$ \\
\hline PP - Fisher & $90.799 * *$ & $198.199 * * *$ & $97.032 * *$ & $225.015 * * *$ & $186.935^{* * *}$ \\
\hline \multicolumn{6}{|l|}{ First difference } \\
\hline Levin, Lin \& Chu t* & $-13.605 * * *$ & $-24.950 * * *$ & $-20.227 * * *$ & $-26.851 * * *$ & $-29.109 * * *$ \\
\hline Im, Pesaran and Shin & $-10.216 * * *$ & $-21.419 * * *$ & $-17.042 * * *$ & $-31.578 * * *$ & $-31.314 * * *$ \\
\hline ADF - Fisher & $232.672 * * *$ & $420.581 * * *$ & $354.162 * * *$ & $567.393 * * *$ & $558.720 * * *$ \\
\hline PP - Fisher & $264.972 * * *$ & $514.394 * * *$ & $461.815^{* * * *}$ & $622.079 * * *$ & $615.639 * * *$ \\
\hline
\end{tabular}

Note: $* * *$ indicates $1 \%$ significance level, $* *$ indicates $5 \%$ significance level. Foreign direct investment and economic growth are in their natural logarithm hence lnfdi and lngdppc.

\begin{tabular}{|c|c|c|c|c|c|}
\hline $\begin{array}{l}\text { Correlation } \\
\text { Probability } \\
\end{array}$ & Infdi & lngdppc & polstab & rulelaw & corco \\
\hline $\operatorname{lnfdi}$ & 1 & & & & \\
\hline lngdppc & $-0.157 * * *$ & 1 & & & \\
\hline polstab & $-0.118 * *$ & $0.330 * * *$ & 1 & & \\
\hline rulelaw & -0.018 & $0.248 * * *$ & $0.671^{* * * *}$ & 1 & \\
\hline corco & 0.037 & $0.163 * * *$ & $0.579 * * *$ & $0.879 * * *$ & 1 \\
\hline
\end{tabular}

Note: $* * *$ indicates $1 \%$ significance level, $* *$ indicates $5 \%$ significance level.

Foreign direct investment and economic growth are in their natural logarithm hence lnfdi and lngdppc.

\section{Panel cointegration test}

The study performed cointegration test to find out the long run relationship between the dependent and the independent variables to strongly infer on the outcome of the regression results as in the long run impact. The study used Pedroni and Johansen Fisher combined cointegration tests to find out the long run estimation or relationship between the dependent and the independent variables. From the Pedroni test, withindimension three tests out of four confirmed that there is an evidence of cointegration thus there is a long run relationship and between-dimension two tests out of three tests confirmed that there is an evidence of cointegration. Furthermore, the study used the Johansen Fisher cointegration test to cross check the results of the Pedroni test and from the results it can be reported that at None there was no cointegration relationship but from At most 1 to At most 4 there is evidence of cointegration or long run relationship between the dependent and the independent variables. All the results from the two tests showed $1 \%$ significance.

E. Regression results of main methods (GLS random-effects, $M L$-random effects and Fixed effects)

Act of terrorism through crime, violence and civil war which mostly causes political instability and potentially cripples the development of an economic and also unstabilized the growth of the economy. Due to this, the study aimed at assessing the impact of terrorism on foreign direct investment in Sub-Saharan Africa which has witnessed enormous act of terrorism in recent times. In lieu of this objective, the study employed three linear regression methods thus ML random-effect, GLS randomeffect and fixed effects to unravel the linear relationship that exists between terrorism and foreign direct investments in SubSaharan Africa. The outcome of the three regression methods can be found in table 6 and from the table it can be reported that terrorism as political instability (polstab) has negative and statistically significant linear relationship or impact on foreign direct investment in Sub-Saharan Africa. Perhaps, an increase in the score of political instability in Sub-Saharan Africa will lead to a decrease in foreign direct investment by $0.293 \%$, $0.305 \%$ and $0.248 \%$. The economic growth of Sub-Saharan Africa showed negative and statistically significant linear relationship or impact on foreign direct investment. The relationship confirms that as the economy of Sub-Saharan Africa keeps soaring the appetite for foreign direct investment will fall. On the other hand, a percentage increase in economic growth will lead to $0.185 \%, 0.178 \%$ and $0.212 \%$ decrease in foreign direct investment. Moreover, the control of corruption in Sub-Saharan African has prospect of increasing the inflows of foreign direct investments hence there is a positive and statistically significant linear relationship or impact of corruption control on foreign direct investments. By finding the relationship that exist between terrorism and foreign direct investment with control of rule of law; rule of law showed an insignificant relationship or impact on foreign direct investment in Sub-Saharan Africa. 
TABLE 5: Panel Cointegration Tests

\begin{tabular}{|c|c|c|c|c|c|}
\hline \multicolumn{6}{|c|}{$\begin{array}{l}\text { Pedroni Residual Cointegration Test } \\
\text { Alternative hypothesis: common AR coefs. (within-dimension) }\end{array}$} \\
\hline & & \multirow[b]{2}{*}{ Statistic } & \multirow[b]{2}{*}{ Prob. } & \multicolumn{2}{|l|}{ Weighted } \\
\hline & & & & Statistic & Prob. \\
\hline Panel v-Statistic & & $3.605 * * *$ & 0.000 & -1.769 & 0.962 \\
\hline Panel rho-Statistic & & 0.090 & 0.536 & 2.729 & 0.997 \\
\hline Panel PP-Statistic & & $-9.865^{* * *}$ & 0.000 & $-5.768 * * *$ & 0.000 \\
\hline Panel ADF-Statistic & & $-10.218 * * *$ & 0.000 & $-5.013 * * *$ & 0.000 \\
\hline \multicolumn{6}{|c|}{ Alternative hypothesis: individual AR coefs. (between-dimension) } \\
\hline & & Statistic & Prob. & & \\
\hline Group rho-Statistic & & 5.061 & 1.000 & & \\
\hline Group PP-Statistic & & $-9.126^{* * *}$ & 0.000 & & \\
\hline Group ADF-Statistic & & $-5.678 * * *$ & 0.000 & & \\
\hline \multicolumn{6}{|c|}{ Johansen Fisher Panel Cointegration Test } \\
\hline Hypothesized & Fisher Stat.* & & Fisher Stat.* & & \\
\hline No. of CE(s) & (from trace test) & Prob. & (max-eigen test) & Prob. & \\
\hline None & 41.59 & 0.987 & 78.43 & 0.106 & \\
\hline At most 1 & $385^{* * *}$ & 0.000 & $385 * * *$ & 0.000 & \\
\hline At most 2 & $555.4 * * *$ & 0.000 & $555.4 * * *$ & 0.000 & \\
\hline At most 3 & $445.3^{* * *}$ & 0.000 & $357.9 * * *$ & 0.000 & \\
\hline At most 4 & $242.5 * * *$ & 0.000 & $242.5 * * *$ & 0.000 & \\
\hline
\end{tabular}

Note: $* * *$ indicates $1 \%$ significance level. Test used Pedroni and Johansen Fisher combined cointegration tests

TABLE 6: Main Regression Results

\begin{tabular}{|c|c|c|c|}
\hline & $\begin{array}{c}\text { ML } \\
\text { Random-effect }\end{array}$ & $\begin{array}{c}\text { GLS } \\
\text { Random } \\
\text { effect }\end{array}$ & Fixed effect \\
\hline polstab & $\begin{array}{l}-0.293 \\
(-2.38) * *\end{array}$ & $\begin{array}{l}-0.305 \\
(-2.48) * *\end{array}$ & $\begin{array}{l}-0.248 \\
(-2.00)^{* *}\end{array}$ \\
\hline corco & $\begin{array}{l}0.583 \\
(2.14)^{* *}\end{array}$ & $\begin{array}{l}0.567 \\
(2.07)^{* *}\end{array}$ & $\begin{array}{l}0.645 \\
(2.34)^{* * *}\end{array}$ \\
\hline rulelaw & $\begin{array}{l}-0.163 \\
(-0.58)\end{array}$ & $\begin{array}{l}-0.149 \\
(-0.53)\end{array}$ & $\begin{array}{l}-0.213 \\
(-0.76)\end{array}$ \\
\hline lngdppc & $\begin{array}{l}-0.185 \\
(-2.75)^{* *}\end{array}$ & $\begin{array}{l}-0.178 \\
(-2.65)^{* *}\end{array}$ & $\begin{array}{l}-0.212 \\
(-3.15)^{* *}\end{array}$ \\
\hline constant & $\begin{array}{l}3.320 \\
(6.58)^{* * *}\end{array}$ & $\begin{array}{l}3.260 \\
(6.52)^{* * *}\end{array}$ & $\begin{array}{l}3.539 \\
(7.03)^{* * *}\end{array}$ \\
\hline $\begin{array}{l}\text { LR Chi2 } \\
\text { Log likelihood }\end{array}$ & $\begin{array}{l}23.48 * * * \\
-930.037\end{array}$ & & \\
\hline Wald Chi2 & & $23.40 * * *$ & \\
\hline F-statistics & & & $6.44 * * *$ \\
\hline Observations & 495 & 495 & 495 \\
\hline
\end{tabular}

F. Robust check: Generalized linear model and Multivariate regression

In order to statistically and robustly confirm the results of the three linear regression (main regression), the study used generalized linear model and multiviarate regression as robust check methods. From all indications, it is evidenced that the results of the main regressions are statistically good as the robust check methods produced the same results. The robust check methods confirm that terrorism (political instability), rule of law and economic growth have negative and statistically significant linear relationship or impact on foreign direct investment but rule of law showed an insignificant result. Moreover, corruption showed positive and statistically significant linear relationship or impact on foreign direct investment. The results of the robust check can be found in table 7.

\begin{tabular}{lll}
\multicolumn{3}{c}{ TABLE 7: Robust Check Methods } \\
\hline GLM & Multiviarate \\
\hline polstab & -0.305 & -0.305 \\
& $(-2.48)^{* *}$ & $(-2.48)^{* *}$ \\
corco & 0.567 & 0.567 \\
& $(2.07)^{* *}$ & $(2.07)^{* *}$ \\
rulelaw & -0.149 & -0.149 \\
& $(-0.53)$ & $(-0.53)$ \\
lngdppc & -0.178 & -0.178 \\
& $(-2.65)^{* *}$ & $(-2.65)^{* *}$ \\
constant & 3.260 & 3.260 \\
& $(6.52)^{* * *}$ & $(6.52)^{* * *}$ \\
Log likelihood & -930.270 & \\
R-square & & 0.046 \\
F-statistics & & $5.851^{* * *}$ \\
Observations & 495 & 495 \\
\hline
\end{tabular}

Note: $* * *$ indicates $1 \%$ significance level, $* *$ indicates $5 \%$ significance level. T-statistics and Z-statistics are in parentheses. GLM uses Z-statistics and Multiviarate uses T-statistics. Foreign direct investment and economic growth are in their natural logarithm hence lnfdi and lngdppc.

\section{CONCLUSION}

The study aimed at assessing the impact on or relationship that exist between terrorism and foreign direct investment in Sub-Saharan Africa. However, the study utilized panel data of 
33 Sub-Saharan African countries and employed secondary data from the period of 2000 to 2014. The data used for the study were sourced from World Development Indicators and Worldwide Governance Indicators. Generally, since the study was a panel study, it used panel data methodologies to analysis its data to achieve its objective.

The study upon its statistical analysis infer that there is an inverse relationship between terrorism activities (political instability) and foreign direct investment hence heightening the political climate through violence crime and civil war will lead to decrease in inflows of foreign direct investments in SubSaharan Africa. On the other hand, an increase in economic growth will lead to decrease in foreign direct investment or the reliant on foreign direct investment will fall when there is significant increase in the economic growth of Sub-Saharan Africa. In spite of this, control of corruption has positive and significant impact on foreign direct investment inflows in SubSaharan Africa. Corruption is an endemic to development hence any pragmatic approach in fight such menace will propagate development and growth. Therefore, the evidence revealed in the results of the regression analysis is obvious. However, the extent at which judicial and legal entities such as court, police and other law enforcement agencies work independently from the political interference showed insignificant relationship or impact on foreign direct investment in Sub-Saharan Africa. The study has highlighted on the need to strengthen and intensify the security intelligence and forces in Sub-Saharan Africa to wage war against terrorism and possible violences or civil wars which can unstabilitized the political and economic climate of the region. As the study focused on the linear relationship of terrorism activities and foreign direct investments, it recommends further studies into the subjectmatter by employing the non-linear approaches to ascertain the non-linear relationship between the two.

\section{ACKNOWLEDGEMENT}

This study was funded by the National Natural Science Foundation of China with grant numbers: 71701082 and 71271103.

\section{REFERENCES}

[1] Abadie, Alberto and Gardeazabal, Javier (2008) "Terrorism and the World Economy", European Economic Review, Vol 52

[2] Abadie, \& Gandeazaba. (2008). The economic costs of conflicts: A case study of the basque country. The American Economic Review, 93, 113132.

[3] Agrawal, S. (2011). The Impact of Terrorism on Foreign Direct Investment: Which Sectors are More Vulnerable. CMC College,

[4] Alomar, M., \& El-Sakka, M. (2011). The impact of terrorism on the FDI inflows to less developed countries: A panel study. European Journal of Economics, Finance and Administrative Sciences (28), 116-125.

[5] Ayse Y. Evrensel and Ali M. Kutan, (2007) "Are multinationals afraid of social violence in emerging markets?: Evidence from the Indonesian provinces", Journal of Economic Studies, Vol. 34

[6] Bandyopadhyay, S., Sandler, T., \& Younas, J. (2011). Foreign direct investment, aid, and terrorism: ananalysis of developing countries. Unpublished manuscript, Center for Global Collective Action, University of Texas at Dallas. European Economic Review Vol 52
[7] Bandyopadhya, S. Sandler, T. \& Younas, J. (2014). Foreign Direct Investment, Aid, Terrorism. Oxford Economic Paper, 25-50.

[8] Busse, Matthias and Hefeker, Carsten (2007) "Political Risk, Institutions and Foreign Direct Investment", European Journal of Political Economy Vol 23

[9] Blomberg, S. Brock and Mody, Ashoka (2007) "How Severely Does Violence Deter International Investment?" Journal of Monetary Economics, Vol 51.

[10] Gaibulloev, K., \& Sandler, T. (2008). The impact of terrorism and conflicts on growth in Asia, 1970-2004. Working Papers.

[11] Hafsa, R. \& Tahir, M. (2012). FDI \& Terrorism: Co-Integration and Granger Causality. International Affairs \& Global Strategy. Vol 4.

[12] Im, K.S., Pesaran, M.H., Shin, Y. (2003). Testing for unit roots in heterogeneous panels. Journal of Econometrics 115, 53 - 57.

[13] James, Li, T., McCarthy, D., Phumiwasana, T., \& Yago, G. (2006). Economic impacts of global terrorism.level FDI flows" Paper presented at the annual meeting of the Theory vs. Policy? Connecting Scholars and Practitioners, New Orleans Hilton Riverside Hotel, The Loews New Orleans Hotel, New Orleans, USA.

[14] Levin, A., Lin, C.F., Chu, C. (2002). Unit root tests in panel data: asymptotic and finite sample properties. Journal of Econometrics 108, 1 $-24$.

[15] Maddala, G.S., Wu, S. (1999). A comparative study of unit root tests with panel data and a new simple test. Oxford Bulletin of Economics and Statistics 61, 631-652.

[16] Mihalache, Andreea (2010). "Who's afraid of political violence? Evidence from industry level FDI flows" Paper presented at the annual meeting of the Theory vs. PolicyConnecting Scholars and Practitioners, New Orleans Hilton Riverside Hotel, The Loews New Orleans Hotel, New Orleans, USA.

[17] Pedroni, P. (1999). Critical values for cointegration tests in heterogeneous panels with multiple regressors. Oxford Bulletin of Economics and Statistics 61, $53-70$

[18] Pedroni, P. (2004). Panel cointegration: Asymptotic and finite sample properties of pooled time series tests with an application to the PPP hypothesis: New results. Economic Theory 20, $597-627$.

[19] Shahbaz, M.A, Javed, A,. Dar, A., Sattar, T. (2012). Impact of Foreign Direct Investment in Pakistan. Achieves of Business Research, 1(1), 1-7.

[20] Shivani, A. (2011). The impact of terrorism on foreign direct investment: Which sectors are more vulnerable? Claremont Mckenna College (Published Senior thesis).

[21] Wagner, Daniel (2007) "The Impact of Terrorism on Foreign Direct Investment",International Risk Management Institut 